\title{
Impact of stand variables on characteristics of avian soundscape in common oak (Quercus robur L.) forests
}

\author{
Andrey Atemasov* and Tatiana Atemasova
}

\begin{abstract}
Atemasov, A., Atemasova, T. 2019. Impact of stand variables on characteristics of avian soundscape in common oak (Quercus robur L.) forests. - Forestry Studies | Metsanduslikud Uurimused 70, 68-79, ISSN 1406-9954. Journal homepage: http://mi.emu.ee/forestry.studies
\end{abstract}

\begin{abstract}
One of the problems that may arise when conducting long-term monitoring of bird populations in forest landscapes may be discrepancies between data obtained by different researchers. Using acoustic monitoring may solve this problem. To establish the suitability of the acoustic method for monitoring the state of forest ecosystems, studies were conducted in May and June 2018 on seven plots different from each other by stand age and species composition in a maple-linden-oak forest in northeastern Ukraine. The species composition of birds, the structure and composition of the stand and the values of six acoustic indices were calculated. Differences were found in all acoustic indices at different sites. The smallest values of the indices were noted in the overgrown clear-cut. Four acoustic indices in the May survey and five of the six in the June survey show significant correlations with the species richness of birds. All indices correlate with the values of several stand variables, which characterize the size and species composition of the stand, understorey and field vegetation, the closeness of various vegetation tiers, and with the distance to the edges and the nearest populated areas. The results suggest the possibility of using an acoustic approach to monitoring the bird population and the state of forest ecosystems.
\end{abstract}

Key words: bioacoustics, acoustic sampling, ecoacoustic indices, northeastern Ukraine.

Authors' addresses: Department of Zoology and Animal Ecology, School of Biology, V.N. Karazin Kharkiv National University, Svobody Sq. 4, 61022 Kharkiv, Ukraine; *e-mail: atemasov@gmail.com

\section{Introduction}

Forest biodiversity exceeds the biodiversity of other terrestrial ecosystems. Forest ecosystems support about two-thirds of the world's terrestrial biodiversity (Gardner, 2010). One of the goals of ecologically sustainable forestry is the preservation of biological diversity - the diversity of living creatures that inhabit a forest area, at all levels (Lindenmayer et al., 2000). To un- derstand the causes of and predict changes in ecosystems, as well as timely prevent or mitigate the negative effects of economic activities, it is necessary to monitor biodiversity with an assessment of their share by abundance or biomass (Sokolov \& Reshetnikov, 1997; Ravkin \& Ravkin, 2005).

Birds are effective indicators of the ecological integrity of forests and sustainable forest management. They are very diverse and have the ability to respond to processes occurring 
in ecosystems, plus their identification is relatively simple for qualified observers (Venier \& Pearce 2007; Venier et al., 2017). Bird monitoring techniques are relatively well developed (for example, Ralph \& Scott, 1981; Priedniks et al., 1986; Bibby et al., 1992; and others). However, during long-term monitoring and, accordingly, participation in the work of several successive researchers, there may be a problem associated with the discrepancy between the data obtained by different researchers. Ornithologists have accumulated rich material on the influence of the subjective factor on the results of surveys (see review: Morozov, 1997). Discrepancies between the results of different researchers arise from the fact that in the course of field work, observers miss different numbers of individuals and species available for registration, make mistakes in determining distances to birds, ambiguously interpret belonging to several individuals or one moving individual of several successive registrations by voice, etc. One way to solve this problem is to use acoustic monitoring.

Passive acoustic monitoring, or simply "acoustic monitoring", includes wildlife monitoring using field recording devices. Recording is carried out within minutes, hours, days or weeks, according to a predetermined schedule. These records are then processed to extract environmental data, such as the detection of specific animal species or species richness in general (Browning et al., 2017). As opposed to the bioacoustic interest in separate species, soundscape ecology study the distribution of sound through a landscape (Pijanowski et al., 2011a, 2011b; Farina, 2014; Towsey et al., 2014). To measure the quality of habitats using recordings, some acoustic indices have been proposed. In this paper, we study the dependence of the values of acoustic indices on the number of breeding bird species and various stand variables in the upland maple-linden oak forest in northeastern Ukraine.

\section{Material and Methods}

The research was conducted on the territory of the National Nature Park "Gomilshansky forests" $\left(49^{\circ} 35^{\prime} \mathrm{N}, 36^{\circ} 20^{\prime} \mathrm{E}\right)$. It is located in the northeastern part of Ukraine, in the central part of the Kharkiv region, on the territory of the Zmiivsky and Pervomaysky districts and occupies an area of $14,314.8$ hectares. The park covers a large forest area on the right bank of the Siversky Donets River, the floodplain of the river, and the left-bank borough terrace. According to the physical-geographical zoning, the park's territory belongs to the Kharkov slope-elevated region of the Central Russian forest-steppe province of the Forest-Steppe Zone. The climate in the area is moderately warm with variable moistening. The average long-term air temperature is $7{ }^{\circ} \mathrm{C}$, the average July temperature is $21.5^{\circ} \mathrm{C}$, the average annual precipitation is $511 \mathrm{~mm}$. The duration of the frost-free period is 155-160 days. The depth of the snow cover is $18-20 \mathrm{~cm}$, the time of occurrence of the snow cover is about 3 months (Prokudin, 1980).

One of the zonal vegetation types of the Left-Bank Forest-Steppe of Ukraine is the oak forests, and the main part of the National Nature Park "Gomilshansky forests" is one of the best old oak massifs on the Left Bank of Ukraine. Also on the territory of the park is a vegetation complex characteristic of the valleys of the rivers of the Forest-Steppe Zone of Ukraine: pine and oak-pine forests of the sandy terraces; floodplain oak forests; alder, willow and poplar forests; flood meadows. It also includes areas of steppe vegetation, small swamps and aquatic vegetation (Prokudin, 1980). Terrestrial phytocoenoses of this territory are gradually changing. This is especially true for recreational areas along the banks of the Siversky Donets River, where the phytocenotic and floristic structure of the communities is violated. Oak and birch are almost not involved in the regeneration of the indigenous forests of the park, 
the change of typical associations in connection with the predominance of meadow and steppe species continues, and there is a danger of their transition to non-forest associations (Gorelova, 1989).

Studies were conducted on seven plots on the territory of the Koropovskoye forestry:

- Plot A. 90-107-year-old oak forest near the biological station of the V.N. Karazin Kharkiv National University, forest quarters 3 and 4. Composition of the stand: common oak Quercus robur L. $(60 \%)$, small-leaved lime Tilia cordata Mill. (20\%), Norway maple Acer platanoides L., European ash Fraxinus excelsior L. (10\% each), vegetative origin. Height 12-22 m. Undergrowth: field maple Acer campestre L., Norway maple and small-leaved lime, aged 20-25 years, height 6-8 m, silver birch Betula pendula Roth, common hazel Corylus avellana $\mathrm{L}$. The composition of the plantings is heterogeneous, the planting is uneven. There are small glades. The slope of the northwestern and northeastern exposure is 10-15 degrees.

- Plot B. 100-112-year-old oak forest near Gaydary village, forest quarter 2. Composition of the stand: common oak $(70 \%)$, European ash $(20 \%)$, smallleaved lime $(10 \%)$, vegetative origin. Height 21-26 m. Undergrowth: field maple, Norway maple and elm Ulmus sp., aged 20-25 years, height $6 \mathrm{~m}$, silver birch, common hazel. The composition of the plantings is heterogeneous, the planting is uneven.

- Plot C. 90-127-year-old oak forest, forest quarters 4 and 8. Composition of the stand: common oak $(70 \%)$, smallleaved lime $(30 \%)$, vegetative origin. Height 22-25 m. Undergrowth: Norway maple, elm, small-leaved lime and euonymus Euonymus verrucosus Scop., aged 20 years, height $8 \mathrm{~m}$, silver birch, common hazel. The composition of the plantings is heterogeneous, the planting is uneven.
- Plot D. 97-year-old oak forest, forest quarter 7. Composition of the stand: common oak $(90 \%)$, elm $(10 \%)$, vegetative origin. Height $24 \mathrm{~m}$. Undergrowth: field maple, Norway maple, elm and small-leaved lime, aged 20 years, height $8 \mathrm{~m}$, silver birch, common hazel.

- Plot E. 47-49-year-old maple forest, quarter 20. Composition of the stand: elm $(40 \%)$, Norway maple $(30 \%)$, common oak (20\%), small-leaved lime (10\%), vegetative origin. Height 16-19 $\mathrm{m}$. Undergrowth: field maple and Norway maple, height $6 \mathrm{~m}$, common hazel. Plot F. Overgrown clear-cut, quarter 20. Unclosed forest cultures (common oak). Natural origin (small-leaved lime $30 \%$, common hazel $50 \%$, field maple $20 \%$ ).

- Plot G. 62-87-year-old aspen forest, quarters 4 and 8 . Composition of the stand: common aspen Populus tremula L. $(50 \%)$, small-leaved lime (40\%), common oak $(10 \%)$, vegetative origin. Height 19-24 m. Undergrowth: Norway maple, elm, small-leaved lime and euonymus, aged 20 years, height 8 m, Tatar maple Acer tataricum L., elm, common hazel.

At each plot five points were set at a distance of 100 meters from each other in a straight line. The audio recording was performed at each point on May 22-24 and June 6-8, 2018 from 5:00 to 8:00. The duration of each record was 5 minutes. The recording was performed using the Tascam DR-05 Digital Recorder, mounted on a tripod. The recorders were set at $44 \mathrm{kHz} / 24 \mathrm{bit} / \mathrm{stereo}$ mode. Each record was divided into 25 intervals for 12 seconds. For each interval, six acoustic indices (AI) were calculated:

Acoustic Complexity Index (ACI). Created for quantification of the birds' vocalizations by processing the intensities registered in audio-files (Farina \& Morri, 2008; Pieretti et al., 2011). The formula of the ACI is developed based on the assumption that biotic sounds 
are characterized by an intrinsic variability of intensities, while humangenerated noise presents constant intensity values.

- Acoustic Diversity Index (ADI). Calculated as the Shannon index using the proportions of the signals in each bin above the threshold value (Pijanowski et al., 2011a, 2011b; Villanueva-Rivera et al., 2011).

- Acoustic Evenness Index (AEI). Estimates the diversity of sounds with the Gini Index (Villanueva-Rivera et al., 2011).

- Bioacoustic Index (BI). Calculated as the area under the mean frequency spectrum. Proposed by Boelman et al. (2007) as a measure of the number of birds.

- Normalized Difference Soundscape Index (NDSI). Evaluates the level of anthropogenic disturbances, calculating the ratio of biophony and anthropophony (Kasten et al., 2012).

- Acoustic Entropy Index $(\mathrm{H})$. This is a product of spectral and temporal entropies which are calculated on the mean spectrum and Hilbert amplitude envelope of a time wave, respectively (Sueur et al., 2008).

The soundecology package (Villanueva-Rivera \& Pijanowski, 2015) for R (R Core Team, 2018) was used for AI calculations. For each record, 25 AI values were obtained corresponding to 12 second intervals. Average AI values were calculated for each point, which were used in further analysis. The one-way analysis of variance (ANOVA) was used to determine whether there are any statistically significant differences between the values of the indices in different forest stands.

The number of bird species was determined for each point by listening to recordings. Listening to the recordings and spectrogram visualizations was performed using the Audacity v.2.3.0 software. Pearson's coefficient of correlations was used to examine relationships between the $\mathrm{AI}$ and number of bird species and between the AI and stand variables.

The description of phytocoenoses at each point is made according to standard methods (James \& Shugart, 1970; Ambuel \& Temple, 1983):

- the number of the trunks of bushes on two transects with approx. width $2 \mathrm{~m}$ (the width of the hands extended to the sides ) were counted in three height classes: low $0.5-1.0 \mathrm{~m}$, average 1.0-3.0 m, high > $3.0 \mathrm{~m}$;

- trunks of trees were counted by species in eight dimensional classes on the basis of diameter at breast height (DBH), then united in four classes: small 7-22 $\mathrm{cm}$, average $22-37 \mathrm{~cm}$, large $37-52 \mathrm{~cm}$, massive $>52 \mathrm{~cm}$. The standing dead trees, irrespective of their size and appearance, were registered in a separate category. Also the quantity of thick (>20 cm in diameter) dry branches on living trees and the quantity of trees lying on the ground were counted; importance value (IV) was calculated for each tree species according to the formula:

$$
\begin{aligned}
& I V_{i}=\left(\text { stems }_{i} / \text { stems }_{\text {total }}\right) / 2+ \\
& +\left(\text { basal_area }_{i} / \text { basal_area }_{\text {total }}\right) / 2
\end{aligned}
$$

where stems is the number of tree trunks of the species $i$, stems total $_{\text {in }}$ is the total number of trunks of trees, basal_area is calculated for each species based on the data on the $\mathrm{DBH}$ and basal_area ${ }_{\text {total }}$ is calculated for all types based on the data on the $\mathrm{DBH}$;

- the foliage profile was described at 20 randomly selected points. At each point, the presence or absence of vegetation in the four elevated zones was determined: grassy vegetation and low shrubs 0-0.5 m, shrubs 0.5-3.0 m, undergrowth 3.0-10.0 m, woody vegetation > $10 \mathrm{~m}$;

Foliage Height Diversity (FHD) was calculated using the formula:

$$
\mathrm{FHD}=\sum 1 / \mathrm{p}_{\mathrm{i}}^{2}
$$


- Foliage Profile Diversity (FPD) was calculated using the formula:

$$
F P D=-\sum p_{i} \log p_{i}
$$

The distance from each point to the edge of the forest inventory unit, the edge of the forest and the nearest settlement was also calculated. Statistical processing was carried out using R 3.5.1 (R Core Team, 2018).

\section{Results}

The analysis conducted using one-way ANOVA, showed significant differences in the values of the indices in different forest stands in May and June, except for the ACI in May (Figure 1). In order to find out at which points the indices were different from the other, Tukey's criterion was applied. It has been established that for many of the indicators, it differs from the other in plot $\mathrm{F}$ located on the overgrown clear-cut. In this plot, diversity indices (ACI, ADI, BI, $\mathrm{H}, \mathrm{NDSI})$ are lower than those in the remaining plots, whereas the AEI is higher.

In June, compared with May, some indicators were changing. Thus, $\mathrm{H}$ decreased in all plots except in plot D (90-year-old oak forest). The ADI decreased in plot A (90-107-year-old oak forest near the biostation) and G (aspen forest), BI and NDSI in plot C (90-127-year-old ripe oak forest). On the contrary, the AEI increased in plots A, E (maple forest) and G.

A total of 26 bird species were recorded on the recordings (21 in May, 24 in June). The number of species registered at each site is presented in Table 1. In May, the ADI, H, NDSI positively correlated and the AEI negatively correlated with the number of species; in June, the ADI, BI, H, NDSI positively correlated and the AEI negatively correlated with the number of species (Table 2).

Table 1. Species richness of birds in the plots.

\begin{tabular}{lcccc}
\hline Plot & \multicolumn{2}{c}{ May } & \multicolumn{2}{c}{ June } \\
\cline { 2 - 5 } & $\begin{array}{c}\text { Total number of } \\
\text { species in plot }\end{array}$ & $\begin{array}{c}\text { Average number of species } \\
\text { in point }\end{array}$ & $\begin{array}{c}\text { Total number of } \\
\text { species in plot }\end{array}$ & $\begin{array}{c}\text { Average number of } \\
\text { species in point }\end{array}$ \\
\hline A & 13 & $7.60 \pm 0.75$ & 14 & $6.80 \pm 0.49$ \\
B & 11 & $6.00 \pm 0.84$ & 14 & $6.60 \pm 0.60$ \\
C & 15 & $8.00 \pm 0.32$ & 15 & $6.80 \pm 0.20$ \\
D & 11 & $5.60 \pm 0.60$ & 12 & $6.60 \pm 0.24$ \\
E & 10 & $5.60 \pm 0.68$ & 10 & $5.00 \pm 0.32$ \\
F & 10 & $2.80 \pm 0.80$ & 9 & $3.60 \pm 0.75$ \\
G & 14 & $7.20 \pm 0.97$ & 13 & $6.00 \pm 0.45$ \\
\hline
\end{tabular}

Table 2. Correlation rates between acoustic indices and bird species richness.

\begin{tabular}{lcc}
\hline Indices & May & June \\
\hline $\mathrm{ACI}$ & 0.06 & 0.33 \\
$\mathrm{ADI}$ & $0.72^{*}$ & $0.53^{*}$ \\
$\mathrm{AEI}$ & $-0.70^{*}$ & $-0.47^{*}$ \\
$\mathrm{BI}$ & 0.15 & $0.46^{*}$ \\
$\mathrm{H}$ & $0.52^{*}$ & $0.42^{*}$ \\
$\mathrm{NDSI}$ & $0.50^{*}$ & $0.43^{*}$ \\
\hline${ }^{*} \mathrm{p}<0.05$ & &
\end{tabular}

Correlation coefficients between the values of acoustic indices and stand variables were calculated. The greatest correlation was observed for the number of trees of the average size class (DBH from 22 to $37 \mathrm{~cm}$ ), the coefficient of significance for aspen, maple, oak and birch, the number of shrubs up to 3 $\mathrm{m}$ high, the closeness of the first tree tier and the undergrowth, FHD and FPD, the distance to the forest edge (Table 3 ). The number of small trees (DBH from 7 to $22 \mathrm{~cm}$ ), the 

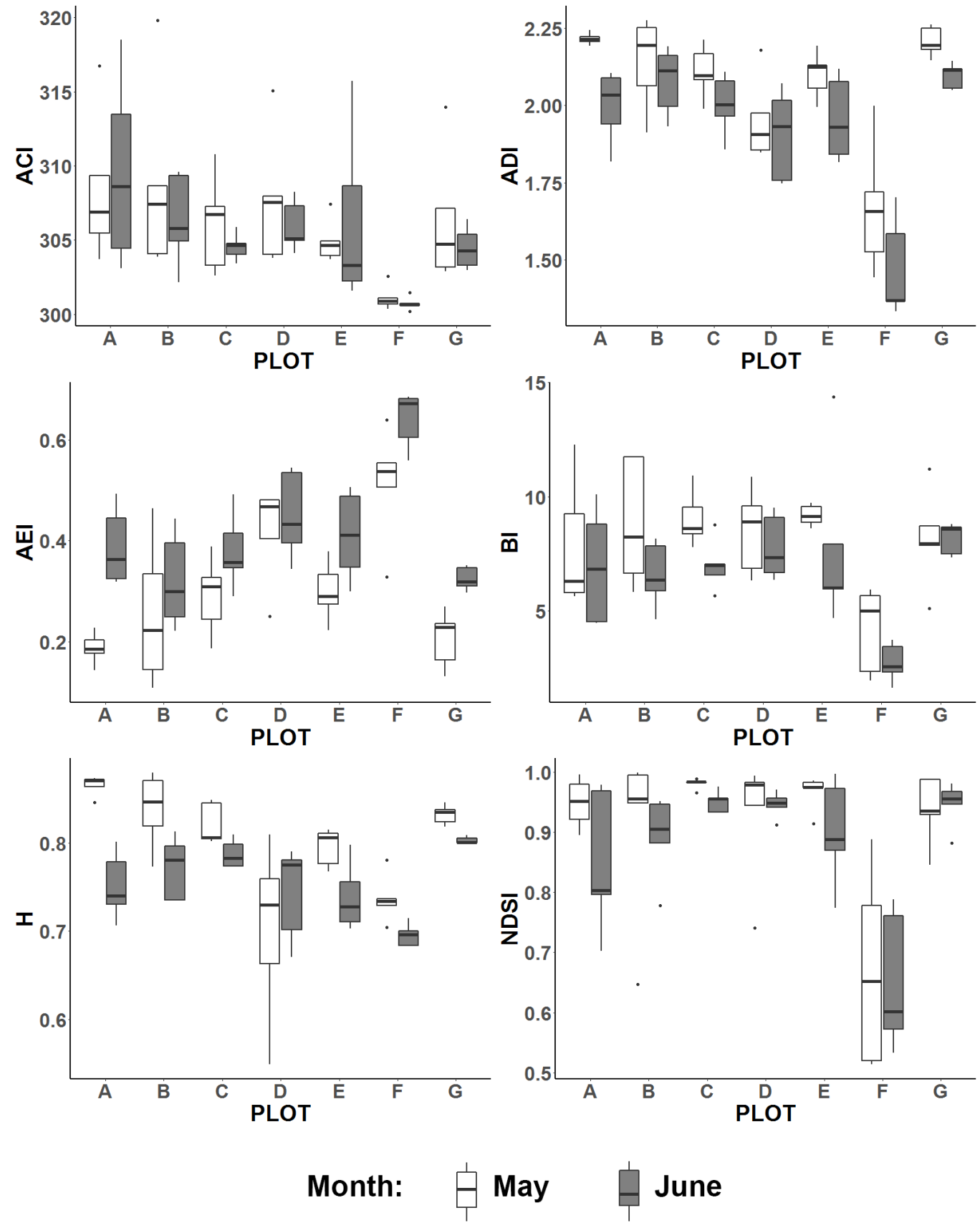

Figure 1. The value of acoustic indices in the studied plots in May and June 2018. 
Table 3. Correlation coefficients of acoustic indices with phytocenosis parameters $(p<0.05)$.

\begin{tabular}{|c|c|c|c|c|c|c|c|c|c|c|c|c|c|c|c|}
\hline \multirow[t]{3}{*}{ Index } & \multirow[t]{3}{*}{ Month } & \multicolumn{14}{|c|}{ Phytocenosis parameters } \\
\hline & & \multicolumn{7}{|c|}{ Number of trees } & \multicolumn{7}{|c|}{ Importance value (IV) of trees } \\
\hline & & 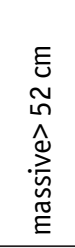 & 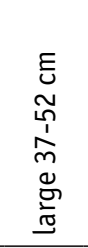 & 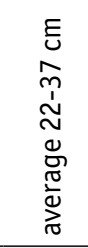 & 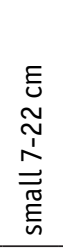 & $\begin{array}{l}\mathbb{Z} \\
\mathbb{\mathbb { Z }} \\
\mathbb{0}\end{array}$ & 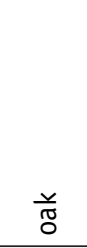 & $\frac{5}{\tilde{n}}$ & $\stackrel{\mathscr{E}}{=}$ & $\begin{array}{l}\stackrel{0}{O} \\
\stackrel{0}{0} \\
\Xi\end{array}$ & $\frac{E}{d}$ & $\begin{array}{l}\bar{\varpi} \\
\bar{\varpi} \\
\bar{\sigma}\end{array}$ & 竞 & $\frac{i}{\frac{i}{0}}$ & 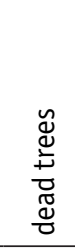 \\
\hline \multirow{2}{*}{ ACI } & May & & & & & & 0.42 & & & & & & & & \\
\hline & June & 0.43 & 0.34 & & & & 0.47 & & & & & & & & \\
\hline \multirow{2}{*}{ ADI } & May & & & 0.61 & & 0.37 & & & & & -052 & -0.50 & & & 0.33 \\
\hline & June & & & 0.52 & & 0.40 & 0.35 & & & 0.36 & & -0.61 & -0.46 & & \\
\hline \multirow{2}{*}{ AEI } & May & & & -0.60 & & -0.34 & & & & & 0.41 & 0.41 & & & \\
\hline & June & & & -0.47 & & -0.38 & -0.36 & & & & & 0.52 & 0.44 & & \\
\hline \multirow{2}{*}{$\mathrm{BI}$} & May & & & & & & & & & 0.43 & & & & & \\
\hline & June & & & & & 0.39 & & & & 0.42 & & -0.45 & -0.42 & & \\
\hline \multirow{2}{*}{$\mathrm{H}$} & May & & & 0.39 & & & & & & & & & & & \\
\hline & June & & & 0.46 & & 0.40 & & & & & & & & 0.43 & \\
\hline \multirow{2}{*}{ NDSI } & May & & & 0.38 & & 0.37 & & & & 0.38 & -0.45 & -0.39 & & & 0.35 \\
\hline & June & & 0.35 & 0.42 & & 0.40 & & & & 0.48 & & -0.58 & -0.43 & & \\
\hline
\end{tabular}

Table 3. (continuation)

\begin{tabular}{|c|c|c|c|c|c|c|c|c|c|c|c|c|c|c|}
\hline \multirow[t]{3}{*}{ Index } & \multirow[t]{3}{*}{ Month } & \multicolumn{13}{|c|}{ Phytocenosis parameters } \\
\hline & & \multicolumn{3}{|c|}{ Number of shrubs } & \multicolumn{5}{|c|}{ Closeness } & FHD & FPD & \multicolumn{3}{|c|}{ Distance } \\
\hline & & $\begin{array}{l}E \\
0 \\
\dot{-} \\
1 \\
0 \\
0 \\
z \\
0 \\
\end{array}$ & 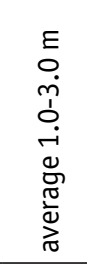 & 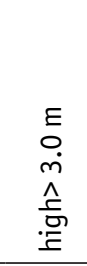 & $\stackrel{\varpi}{\Perp}$ & 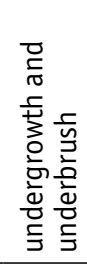 & $\begin{array}{l}\text { ñ } \\
\stackrel{n}{n} \\
\text { n }\end{array}$ & $\begin{array}{l}\tilde{\widetilde{\sigma}} \\
\vdots \\
\vdots\end{array}$ & 气 & & & 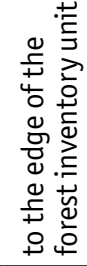 & 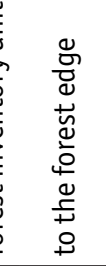 & 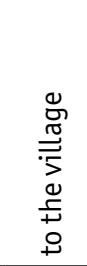 \\
\hline \multirow{2}{*}{$\mathrm{ACI}$} & May & & & & 0.50 & & & & & & & & -0.44 & -0.41 \\
\hline & June & & 0.35 & -0.37 & 0.53 & -0.48 & & & & & & & & \\
\hline \multirow{2}{*}{ ADI } & May & 0.67 & 0.67 & & 0.70 & -0.52 & 0.34 & & 0.47 & -0.41 & 0.37 & & -0.52 & \\
\hline & June & 0.68 & 0.62 & -0.36 & 0.76 & -0.53 & & & 0.60 & -0.53 & 0.60 & & -0.58 & -0.43 \\
\hline \multirow{2}{*}{ AEI } & May & -0.61 & -0.63 & & -0.58 & 0.37 & -0.35 & & & & & & 0.44 & \\
\hline & June & -0.66 & -0.60 & & -0.70 & 0.47 & & & -0.54 & 0.46 & -0.59 & & 0.54 & 0.43 \\
\hline \multirow{2}{*}{$\mathrm{BI}$} & May & & & -0.41 & 0.58 & -0.51 & & 0.45 & 0.49 & -0.42 & 0.43 & & & \\
\hline & June & 0.40 & 0.48 & -0.38 & 0.66 & -0.48 & & 0.39 & 0.57 & -0.52 & 0.38 & 0.41 & -0.34 & \\
\hline \multirow{2}{*}{$\mathrm{H}$} & May & 0.40 & 0.63 & & & -0.35 & 0.46 & & & & & -0.50 & & \\
\hline & June & 0.58 & 0.60 & & 0.47 & & & & 0.42 & & 0.62 & & -0.53 & \\
\hline \multirow{2}{*}{ NDSI } & May & 0.40 & 0.49 & -0.46 & 0.66 & -0.60 & & 0.36 & 0.51 & -0.45 & 0.35 & & -0.40 & \\
\hline & June & 0.50 & 0.42 & -0.39 & 0.64 & -0.52 & & 0.48 & 0.58 & -0.51 & 0.57 & 0.34 & -0.49 & \\
\hline
\end{tabular}


coefficients of significance for ash and lindens did not correlate with the acoustic indices value. The number of trees larger than $37 \mathrm{~cm}$ in diameter, the importance value of poplar and dead trees slightly correlated with the acoustic indices value.

\section{Discussion}

To date, a number of studies have been conducted covering different ecosystems to determine whether the values of the various acoustic indices correspond to the bird diversity values obtained by traditional methods. For example, studies in Brazil's rainforests have shown that both the ACI and BI correlate with the number of bird species (Jorge et al., 2018). Differences in ADI and NDSI meanings correspond to differences in the species composition and structure of bird communities between the gallery and cerrado forest in Central Brazil. (Machado et al., 2017). The results of studies conducted at sites of varying degrees of degradation (from forests to agricultural land) in southeastern England and northwestern Ecuador showed that the greatest correlation (up to $65 \%$ ) between acoustic indices and the number of bird species was observed in a temperate climate (Eldridge et al., 2018).

However, the results of a number of studies failed to indicate a significant correlation of acoustic indices with the number of species. Thus, studies conducted in two regions in the south of China showed that only three indicators (ADI, AEI and H) showed moderate correlations. A slight correlation was shown by the NDSI index. The remaining indices (ACI, $\mathrm{BI}$ and acoustic richness index ARI) did not correlate with species richness (Mammides et al., 2017).

The results of our research also show that not all index values correlate with the species richness of birds. The ACI showed no correlation in either the May or June survey. The BI showed no significant correlation in the May survey. But, most indices correlate with the number of bird species in both surveys, which confirms the idea that acoustic indices can potentially be used to monitor bird communities (Sueur \& Farina, 2015).

According to research results, the use of a single index does not always allow the relationship between its value and the species richness of birds. Therefore, some researchers have proposed the use of combinations of indices (Towsey et al., 2014; Retamosa Izaguirre et al., 2018). The integration of several acoustic parameters allowed to characterize and identify habitats with varying degrees of disturbance (mature forest, secondary growth and pasture) in Colombia (Gómez et al., 2018) accurately predicted the diversity of birds in India (Buxton et al., 2018), etc. A multivariate analysis of the relative predictive power of acoustic indices shows that composite indices are more powerful predictors of bird species richness than any particular index (Eldridge et al., 2018).

The results of a significant part of the studies show that forest bird species are sensitive to stand age and tree species composition as well as the amount of dead wood (Thompson et al., 1999; Walankiewicz et al., 2002, 2011; Roberge et al., 2008; Tozer et al., 2010; Czeszczewik et al., 2013; and others). Across the forest landscape, anthropogenic effects that determine the spatial mosaic of forest age-classes and size of forest patches, also influence the avian species composition and abundance. Very often the richness, abundance and diversity of bird communities are the highest in natural or in semi-natural stands and the lowest in managed stands (Guziy, 2006; Atemasov et al., 2011; Czeszczewik et al., 2015; and others).

Given the correlation of acoustic indices with the species richness of birds and the relationship of the latter with the structure of forest landscapes, it can be assumed that acoustic indices can serve as an indicator of the state of forest ecosystems. Studies carried out in recent years confirm this assumption. A pilot study was conducted to 
test whether soundscapes can be related to the vegetation condition within three broad vegetation conditions of a woodland ecosystem (cleared, regrowth and remnant) in Queensland, Australia ( $\mathrm{Ng}$ et al., 2018). The results of this investigation have shown that three soundscape indices (AEI, $\mathrm{ADI}$ and $\mathrm{H}$ ) were significantly different between vegetation condition types. Authors conclude that differences in the ecosystem condition can be detected as differences in the soundscape. A study conducted in a lowland neotropical rainforest in Costa Rica showed that the composition of acoustic frequency bands and acoustic diversity are strongly linked with the vertical structure of the local canopy in forested environments (Pekin et al., 2012). The results of a research conducted in an agroforestry system in New Franklin, Missouri, demonstrated positive relationships between soundscape composition and vegetative structure (Bobryk et al., 2016). The results of these and other similar studies support soundscapes as a potential measure of the vegetation condition for assessing biodiversity values.

The results of our research show that acoustic indices correlate with several stand variables characterizing the size and species composition of stand, undergrowth, closeness of different vegetation tiers, Foliage Height Diversity and Foliage Profile Diversity, distance to forest edges and the nearest populated areas. Our results support the use of community-level acoustic indices as a point to the potential for tracking subtler habitat-dependent changes in a community composition.

To date, a significant number of studies have been conducted to determine appropriate point-count durations and sample sizes for bird surveys during the breeding season. It was established that the number of registered species increases with the increase in the point-count duration and the number of samples per season (Fuller \& Langslow, 1984; Hutto et al., 1986; Sorace et al., 2000; Shiu \& Lee, 2003; Matsuoka et al., 2014; Balestrieri et al., 2017; Sólymos et al.,
2018; and others). The amount of underestimation during 5-minute point counts can reach $50 \%$ of the total number of species, although usually the proportion of missed species is much smaller. Despite this, the 5-minute point count is a standard method for monitoring birds (Bibby et al., 1992; Ralph et al., 1995). When applying acoustic methods, this problem can be solved by using stand-alone devices that can conduct audio recording for an extended time.

\section{Conclusion}

The results of our research revealed that acoustic indices (ADI, AEI, BI, H, NDSI) showed a correlation not only with the species richness of birds, but also with different stand variables, which characterize its structure and species composition of the plant cover. In addition, the values of the indices differed for sites with different stand age and species composition. The smallest values of the indices were noted on the overgrown clear-cut. Thus, the use of acoustic indices can be one of the tools for assessing the state of forest landscapes. Further research is planned to be carried out using autonomous sound recording devices that allow recording for an extended time. This will allow us to trace the dynamics of changes in acoustic indices during the entire nesting season of birds.

\section{References}

Ambuel, B., Temple, S.A. 1983. Area-dependent changes in the bird communities and vegetation of southern Wisconsin forests. Ecology, 64(5), 1057-1068.

Atemasov, A.A., Atemasova, T.A., Devyatko, T.N., Lysenko, N.G., Goncharov, G.L. 2011. The structure of the communities of breeding birds in oak forests on elevated positions in the southern part of Middle Russian Hills. - Birds ecology: species, communities, interrelations. Part 1. - Proceedings of the Meeting Commemorating the $150^{\text {th }}$ Anniversary of the Birth of Nikolay N. Somov (1861-1923), Ukraine, Dec. 2011. Kharkov, 345-354. (In Russian with English summary). 
Balestrieri, R., Basile, M., Posillico, M., Altea, T., Matteucci, G. 2017. Survey effort requirements for bird community assessment in forest habitats. - Acta Ornithologica, 52(1), 1-9.

Bibby, C.J., Burgess, N.D., Hill, D.A. 1992. Bird Census Techniques. London, Academic Press. 257 pp.

Bobryk, Ch.W., Rega-Brodsky, C.C., Bardhan, S., Farina, A., He, H.S., Jose, S. 2016. A rapid soundscape analysis to quantify conservation benefits of temperate agroforestry systems using low-cost technology. - Agroforestry Systems, 90(6), 997-1008.

Boelman, N.T., Asner, G.P., Hart, P.J., Martin, R.E. 2007. Multi-trophic invasion resistance in Hawaii: bioacoustics, field surveys, and airborne remote sensing. - Ecological Applications, 17, 2137-2144.

Browning, E., Gibb, R., Glover-Kapfer, P., Jones, K.E. 2017. Passive acoustic monitoring in ecology and conservation. WWF Conservation Technology Series 1(2). Woking, United Kingdom, WWF-UK. 75 pp.

Buxton, R.T., Agnihotri, S., Robin, V.V., Goel A., Balakrishnan, R. 2018. Acoustic indices as rapid indicators of avian diversity in different landuse types in an Indian biodiversity hotspot. Journal of Ecoacoustics, 2, \#GWPZVD.

Czeszczewik, D., Walankiewicz, W., Mitrus, C., Tumiel, T., Stanski, T., Sahel, M., Bednarczyk, G. 2013. Importance of dead wood resources for woodpeckers in coniferous stands of the Białowieża Forest. - Bird Conservation International, 23, 414-425.

Czeszczewik, D., Zub, K., Stanski, T., Sahel, M., Kapusta, A., Walankiewicz, W. 2015. Effects of forest management on bird assemblages in the Białowieża Forest, Poland. - iForest, 8, 377-385.

Eldridge, A., Guyot, P., Moscoso, P., Johnston, A., Eyre-Walker, Y., Peck, M. 2018. Sounding out ecoacoustic metrics: Avian species richness is predicted by acoustic indices in temperate but not tropical habitats. - Ecological Indicators, 95(1), 939-952.

Farina, A. 2014. Soundscape Ecology: Principles, Patterns, Methods and Applications. Dordrecht, Springer. 315 pp.

Farina, A., Morri, D. 2008. Source-sink and ecofield: hypotheses and experimental evidence. (Source-sink e eco-field: ipotesi ed evidenze sperimentali). - Atti del X congresso nazionale della SIEP-IALE. Ecologia e governance delpaesaggio: esperienze e prospettive. Bari, 365-372.

Fuller, R.J., Langslow, D.R. 1984. Estimating numbers of birds by point counts: how long should counts last? - Bird Study, 31(3), 195202.

Gardner, T. 2010. Monitoring Forest Biodiversity: Improving Conservation through EcologicallyResponsible Management. London, Routledge. 388 pp.
Gòmez, W.E., Isaza, C.V., Daza, J.M. 2018. Identifying disturbed habitats: a new method from acoustic indices. - Ecological Informatics, $45,16-25$.

Gorelova, L.N. 1989. Protection of vegetation cover in Siversky Donets river basin in Kharkiv region. (Охрана растительного покрова бассейна р. Сев. Донец в пределах Харьковской области). - Kharkov University Bulletin, 330, 23-26. (In Russian).

Guziy, A.I. 2006. Spatio-Typological Organization of Bird Forest Stands in Western Ukraine. (Просторово-типологічна організація населення птахів лісостанів західного регіону України). Zhytomyr, Volyn', Ruta. 448 pp. (In Ukrainian).

Hutto, R.L., Pletschet, S.M., Hendricks, P. 1986. A fixed-radius point count method for nonbreeding and breeding season use. - The Auk, 103(3), 593-602.

James, F.C., Shugart, H.H. Jr. 1970. A quantitative method of habitat description. - Audubon Field Notes, 24(6), 727-736.

Jorge, F.C., Machado, C.G., da Cunha Nogueira S.S., Nogueira-Filho S.L.G. 2018. The effectiveness of acoustic indices for forest monitoring in Atlantic rainforest fragments. Ecological Indicators, 91, 71-76.

Kasten, E.P., Gage, S.H., Fox, J., Joo, W. 2012. The remote environmental assessment laboratory's acoustic library: An archive for studying soundscape ecology. - Ecological Informatics, $12,50-67$.

Lindenmayer, D.B., Margules, C.R., Botkin, D.B. 2000. Indicators of biodiversity for ecologically sustainable forest management. Conservation Biology, 14(4), 941-950.

Machado, R.B., Aguiar, L., Jones, G. 2017. Do acoustic indices reflect the characteristics of bird communities in the savannas of Central Brazil? - Landscape and Urban Planning, 162, 36-43.

Mammides, Ch., Goodale, E., Dayananda, S.K., Kang, L., Chen, J. 2017. Do acoustic indices correlate with bird diversity? Insights from two biodiverse regions in Yunnan Province, south China. - Ecological Indicators, 82, 470477.

Matsuoka, S.M., Mahon, C.L., Handel, C.M., Sòlymos, P., Bayne, E.M., Fontaine, P.C., Ralph, C.J. 2014 Reviving common standards in point-count surveys for broad inference across studies. - The Condor, 116(4), 599-608.

Morozov, N.S. 1997. Observer and analyst variability in ecological research. III. Animal counts: birds. - Biology Bulletin Reviews, 117(2), 196-217. (In Russian with English summary).

Ng, M.-L., Butler, N., Woods, N. 2018. Soundscapes as a surrogate measure of vegetation condition for biodiversity values: A pilot study. Ecological Indicators, 93, 1070-1080. 
Pekin, B.K., Jung, J., Villanueva-Rivera, L.J., Pijanowski, B.C., Ahumada, J.A. 2012. Modeling acoustic diversity using soundscape recordings and LIDAR-derived metrics of vertical forest structure in a neotropical rainforest. - Landscape Ecology, 27(10), 15131522.

Pieretti, N., Farina, A., Morri, D. 2011. A new methodology to infer the singing activity of an avian community: The Acoustic Complexity Index (ACI). - Ecological Indicators, 11, 868873.

Pijanowski, B.C., Farina, A., Gage, S.H., Dumyahn, S.L., Krause, B.L. 2011a. What is soundscape ecology? An introduction and overview of an emerging new science. - Landscape Ecology, 26, 1213-1232.

Pijanowski, B.C., Villanueva-Rivera, L.J., Dumyahn, S.L., Farina, A., Krause, B.L., Napoletano, B.N., Gage, S.H., Pieretti, N. 2011b. Soundscape ecology: the science of sound in the landscape. - BioScience, 61, 203-216.

Priedniks, Ya., Kuresoo, A., Kurlavichus, P. 1986. Recommendations for Ornithological Monitoring in the Baltics. (Рекомендации к орнитологическому мониторингу в Прибалтике). Riga, Zinatne. 65 pp. (In Russian).

Prokudin, Yu.N. 1980. Seversk-Donetsk Nature Complex. (Северско-Донецкий природный комплекс). Kharkov, Vyshcha Shkola. 88 pp. (In Russian).

R Core Team. 2018. R: A language and environment for statistical computing. $\mathrm{R}$ Foundation for Statistical Computing, Vienna, Austria. [WWW document]. - URL https://www.Rproject.org/. [Accessed 2 July 2018].

Ralph, C.J., Droege, S., Sauer, J.R. 1995. Managing and monitoring birds using point counts: standards and applications. - Ralph, C.J., Sauer, J.R., Droege, S. (eds.). Monitoring Bird Populations by Point Counts. Albany, CA, Pacific Southwest Research Station, Forest Service, US. Department of Agriculture, 161168.

Ralph, C.J., Scott, J.M. (eds.) 1981. Estimating Numbers of Terrestrial Birds. Los Angeles, Cooper Ornithological Society. 630 pp.

Ravkin, E.S., Ravkin, Yu.S. 2005. Birds of the Plains of Northern Eurasia: Number, Distribution, and Spatial Organization of Communities. (Птицы равнин Северной Евразии: численность, распределение и пространственная организация сообществ). Novosibirsk, Nauka. 304 pp. (In Russian).

Retamosa Izaguirre, M.I., Ramírez-Alán, O., De la O Castro, J. 2018. Acoustic indices applied to biodiversity monitoring in a Costa Rica dry tropical forest. - Journal of Ecoacoustics, 2, \#TNW2NP.
Roberge, J-M., Angelstam, P., Villard, M-A. 2008. Specialised woodpeckers and naturalness in hemiboreal forests - deriving quantitative targets for conservation planning. - Biological Conservation, 141, 997-1012.

Shiu, H.-J., Lee, P.-F. 2003. Assessing avian pointcount duration and sample size using species accumulation functions. - Zoological Studies, 42(2), 357-367.

Sokolov, V.E., Reshetnikov, Yu.S. 1997. Monitoring of biodiversity in Russia. (Мониторинг биоразнообразия в России). - Sokolov, V.E., Reshetnikov, Yu.S., Shatunovsky, M.I. (eds.). Monitoring of Biological Diversity. Moscow, Russian Academy of Science, 8-15. (In Russian).

Sòlymos, P., Matsuoka, S.M., Cumming, S.G., Stralberg, D., Fontaine, P., Schmiegelow, F.K.A., Song, S.J., Bayne, E.M. 2018. Evaluating time-removal models for estimating availability of boreal birds during point count surveys: sample size requirements and model complexity. - The Condor, 120(4), 765-786.

Sorace, A., Gustin, M., Calvario, E., Ianniello, L., Sarrocco, S., Carere, C. 2000. Assessing bird communities by point counts: repeated sessions and their duration. - Acta Ornithologica, 35(2), 197-202.

Sueur, J., Pavoine, S., Hamerlynck, O., Duvail, S. 2008. Rapid acoustic survey for biodiversity appraisal. - PLoS ONE, 3(12), e4065.

Sueur, J., Farina, A., 2015. Ecoacoustics: the ecological investigation and interpretation of environmental sound. - Biosemiotics, 8, 493502.

Thompson, I.D., Hogan, H.A., Montevecchi, W.A. 1999. Avian communities of mature balsam fir forests in Newfoundland: age-dependence and implications for timber harvesting. - The Condor, 101, 311-323.

Towsey, M., Wimmer, J., Williamson, I., Roe, P. 2014. The use of acoustic indices to determine avian species richness in audio-recordings of the environment. - Ecological Informatics, 21, 110-119.

Tozer, D.C., Burke, D.M., Nol, E., Elliott, K.A. 2010. Short-term effects of group-selection harvesting on breeding birds in a northern hardwood forest. - Forest Ecology and Management, 259, 1522-1529.

Venier, L.A., Pearce, J.L. 2007. Boreal forest landbirds in relation to forest composition, structure, and landscape: implications for forest management. - Canadian Journal of Forest Research, 37, 1214-1226.

Venier, L.A., Mazerolle, M.J., Rodgers, A., Mcllwrick, K.A., Holmes, S., Thompson, D. 2017. Comparison of semiautomated bird song recognition with manual detection of recorded bird song samples. - Avian Conservation and Ecology, 12(2), 2. 
Villanueva-Rivera, L.J., Pijanowski, B.C., Doucette, J., Pekin, B. 2011. A primer of acoustic analysis for landscape ecologists. - Landscape Ecology, 26, 1233-1246.

Villanueva-Rivera, L.J., Pijanowski, B.C. 2015. Soundecology: Soundscape Ecology. R package version 1.3. [WWW document]. - URL http:/ / CRAN.R-project.org/package $=$ soundecology . [Accessed 2 July 2018].
Walankiewicz, W., Czeszczewik, D., Mitrus, C., Bida, E. 2002. Snag importance for woodpeckers in deciduous stands of the Bialowieza forest. (Znaczenie martwych drzew dla zespolu dzieciolow w lasach lisciastych Puszczy Bialowieskiej). - Notatki Ornitologiczne, 43, 61-71. (In Polish with English summary).

Walankiewicz, W., Czeszczewik, D., Tumiel, T., Stański, T. 2011. Woodpeckers abundance in the Białowieża Forest - a comparison between deciduous, strictly protected and managed stands. - Ornis Polonica, 52, 161-168.

Received August 5, 2019, revised September 13, 2019, accepted September 13, 2019 